\title{
Risk and Vulnerability of Settlements along Transmission Pipelines in Ogun and Lagos States, Nigeria
}

\begin{abstract}
Elenwo E. I.1
${ }^{1}$ Department of Geography and Environmental Management, Faculty of Social Sciences University of Port Harcourt,P.M.B.5323, Choba, Rivers State, Nigeria

Abstract: Nigeria is a major oil and gas producer and exporter. One of the modes of transportation of these products both locally and internationally is via pipelines transmissions. The increase in demand for settlement spaces has caused more and more persons to seek refuge along pipeline right of ways. Available statistics has shown that pipeline right of ways has remained a danger zone because the physical environment of an impacted area leaves evidences of degradation on the soil, vegetation and loss of lives and property. This research examined the risk and Vulnerability of settlements along the transmission pipelines of Ogun and Lagos States Nigeria. The method of study includes the primary and secondary sources of data collections. The statistical tool used is the factor analysis and vulnerability assessment. Vulnerability assessment considered the loss of lives from explosions or fire breaks resulting from the vandalization of pipelines as well as the vulnerability of the facility or settlements to these hazards. The factor analysis showed 78.1 percent total variance of seven principal factors with eigen values greater or equal to unity. Hypothesis tested accepted alternate, while row scores showed (-19.273) for pair one, (-52.134) for pair two and (-41.273) for pair three, all exceeds the value of ${ }^{\prime} t$ ' indicated in the table. Vulnerability assessment also shows that the attractiveness of the facility as a target by pipeline vandals makes the settlements very vulnerable and the level of deterrence or defense provided by government or pipeline owners were not adequate to counter measures adopted by the vandals. The research recommends aggressive public enlightenment on dangers settlement along pipelines are exposed to and the weaknesses of enforcement of relevant laws by government. The study advocates the implementation of the laws on allowable minimum distance between transmission pipelines and facilities or structures such as buildings etc.
\end{abstract}

Keywords: Risk, Vulnerability, Settlements, Transmission, Pipelines

\section{Introduction}

Available statistics has shown that pipeline right of ways has remained a danger zone because the physical environment of an impacted area leaves evidences of degradation on the soil, vegetation and loss of lives and property (Esinalu, 2004). The construction and installation of pipeline infrastructures in Nigeria is governed by legislation under the oil pipeline Act (CAP 338 pipelines, 1990 LFN). The Minister of Petroleum Resources through the Director of Petroleum Resources (DPR) provides the environmental guidelines for the operation of oil and gas pipelines and the management of right of ways. The Land Use Decree (1978) confers the ownership and control of land and mineral resources on the state. The consequence of this ordinance is that even though pipeline crosses these communities, they have no stake in the running but are exposed to the hazards, risks and are vulnerable should there be pipeline failures. The fear is more worrisome with the current increase in the level of gas distribution and supply network in Niger Delta and the country at large. This paper shows that the threshold population in the study area that is exposed to the dangers of pipeline disaster is put at about ninety thousand persons $(90,000)$. The issue is that with the distribution network of pipeline in Nigeria covering over $470 \mathrm{~km}$ across the country. The population of persons endangered all over the country could be enormous. Therefore, there is an urgent need to identify these emerging settlements that are growing along the pipeline routes both in rural areas, urban and cities in the country. This would help in managing our pipeline network and identifying high risk areas in terms of population and environmental resources.

\section{The Statement of Problem}

The design and operations of pipelines provide the safest and cheapest means of transportation and distribution of both crude oil and petroleum products especially over long distances. The unfortunate

This article is published under the terms of the Creative Commons Attribution License 4.0

Author(s) retain the copyright of this article. Publication rights with Alkhaer Publications.

Published at: http://www.ijsciences.com/pub/issue/2019-01/

DOI: 10.18483/ijSci.1822; Online ISSN: 2305-3925; Print ISSN: 2410-4477 
scenario is that transmission pipeline network that traverse the length and breadth of Nigeria have of late become sources of harm to human and ecological health disasters in the country with colossal economic losses. The situation has become more with the current increase in the level of gas distribution and supply even to neighbouring West African countries such as Benin, Togo and Ghana. Furthermore, the Federal government of Nigeria has directed the Nigeria National Petroleum Resources and its subsidiary (NGC) to increase its production of gases for the local power plants as well as for exports. These moves calls for more transmission pipelines to be laid and the attendant consequences should their arise such environmental threats as fire outbreak occasioned by loss of integrity of pipeline resulting from soil corrosion, sabotage or equipment failure etc. Available statistics of fire incidents and spills in the last ten years from 2005 to 2014 shows over 2000 cases of pipeline fires and 1500 cases of oil spills (P.P.M.C, 2013) with deaths. This is an alarming for a country regarded as an emerging economy in Africa. The trend is on the increase, not only in number, but in magnitude of damages to the environment, loss of valuable assets, loss of lives and great impact on the national economy. The paper addresses the communities along the West African gas pipeline right of way, identifying the settlements that are most vulnerable by location factor, the hazards and risks faced by these settlements and the need for government to take proactive measures in averting the emerging threats to lives, properties and the environment along this right of way.

\section{Concept of Risk}

Risk, according to USEPA (1991) is the probability of injury, disease or death under specific circumstances. It may be expressed in quantitatively terms with values from $0-1$ or described qualitatively as high or low. All human activities carry some degree of risk. According to (Wharton, 2002) he opines that risk pervades all human activity. A mathematical concept of risk can be represented as the product of probability of adverse event and the severity of the occurrence (Lawrence, 1996). This is expressed in the equation.

Risk $\left(\frac{\text { Consequence }}{\text { Unit time }}\right)=\frac{\text { Frequency }(\text { Events })}{\text { Unit time }} \times \frac{\text { Magnitude }(\text { Consequence })}{\text { Event }}$

Generally,

Risk $=\mathrm{Pc}+\mathrm{f}(\mathrm{P}, \mathrm{c}, \mathrm{x})$

Risk $=\mathrm{f}($ hazard, exposure, safeguards)

Where $\mathrm{f}$ is a function of $\mathrm{P}, \mathrm{c}$ and other relevant variables $\mathrm{x}$. $\mathrm{P}$ is the probability and $\mathrm{c}$ is the consequence of the event. According to (Asante-Duah, 2008) risk could be defined as the likelihood to cause harm as a result of exposure to hazardous situation. This is illustrated with a Venn diagram.
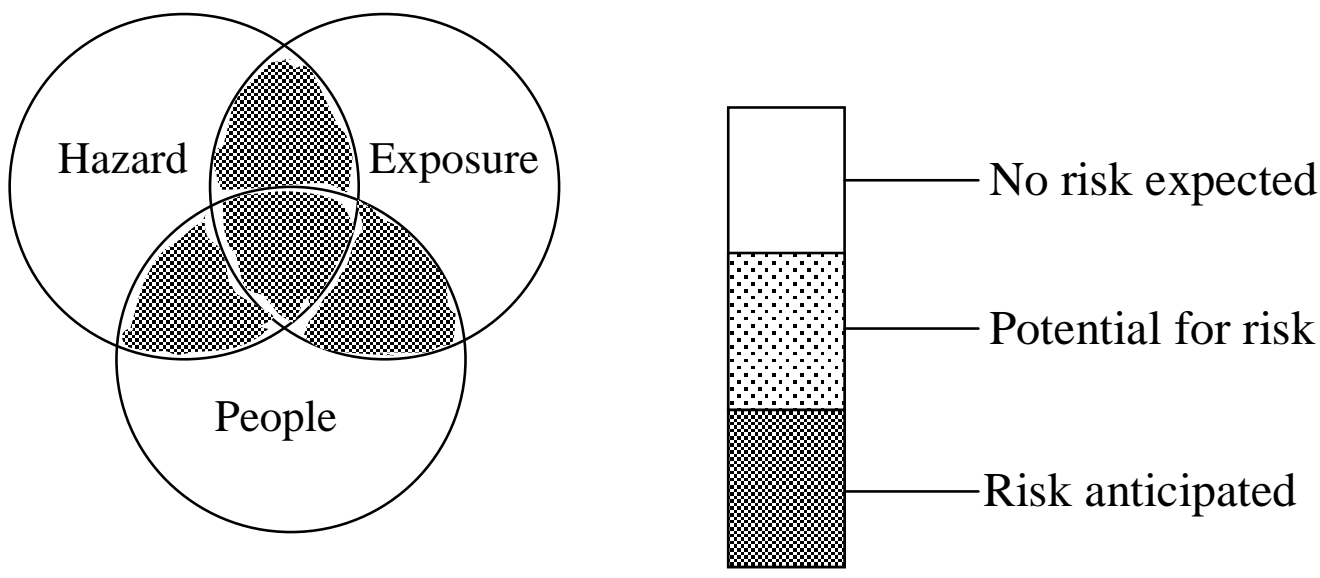

Figure 1: Element and Perception of Risks

Generally speaking risk amongst individuals and groups may even change with time and condition. According to (Schneider,2001) risks that are easy to recall, produce death rather than injuries, take a large number of lives at one place and time or have death consequences. Such risks are often over estimated relative to other risks with same probability time consequences characteristics. Other issues that determine perception of risk include identifiability of victims, attributability, newness and voluntary nature of the risk. Those who occupy the margins of human populations, cultures, societies, and economies often are exposed to hazards hidden from or concealed by those at the center or in the mainstream. Marginality may have its genesis in social class or political economy, as particular groups are pushed out to the 
edge. Marginalization is the factor in the argument of (Slovic, 2014) that causes peasants to make their livelihood in more hazardous environments or to change their uses or resources in ways that exacerbate their vulnerability. Perceptions about risk are influenced by sources of information, styles of presentation, personal background and educational levels, cultural contexts and the dimensions of particular risk problem (Asante-Duah, 2008). A distinction is made between voluntary and involuntary risk. Involuntary risks are those risks which are not willingly undertaken. They are often relatively rare but typically have a catastrophic potential impact. The risk may be unknown to exposed persons. Voluntary risks are those that are more willingly accepted by people through their own actions. Such risks are likely to be more common (Smith, 2010). What level or risk is acceptable is a subject of concern to most authors. To solve the fuzziness, some authors adopt the principle of deminimis risk analysis as against de manifestis risk (Slovic, 2014). While the later reveals the risk levels that are so great that they should not be allowed to happen at all cost, the former are those risk levels that are so insignificantly low. Risk is de minimis if the incremental risk produced by an activity is sufficiently small so that there is no incentive to modify the activity (Cohrassen and Covello, 2009). The concept of de minimis or acceptable risk is essentially a threshold concept or level, below which there would be indifference to changes in level of risk (Asante-

Duah, 2008). Environmental risk is the risk associated with the likelihood or probability that a given exposure or series of exposures may damage human health. This takes two factors into account; the amount of hazard present and its relation to the amount the exposed person can tolerate (USEP, 1991). The continuous use of modem industrial technology could have catastrophic effects on ecological life support system - land erosion and deforestation, the pollution of rivers and oceans, the disturbance of the thermal balance in the atmosphere and possible damage to protective ozone layers in the stratosphere (Wharton, 2002). This is true of the oil industry in Nigeria

\section{Risk Assessment}

According to (Asante-Duah, 2008) environmental risk assessment could be defined as a systematic process for arriving at estimate of all the significant risk factors or parameters associated with the entire range of failure mode and exposure scenarios in connection with some hazardous situation. In the context of management of environmental contamination problems, risk assessment process encompasses an evaluation of all the significant risk factors associated with all feasible and identifiable exposure scenarios that are the result of contaminant releases into the environment. The process seeks to estimate the 1ikelihood of occurrence of adverse effects resulting from exposures of human and ecological receptors to chemical, physical or biological agents that are present in the environment, utilizing the best available scientific knowledge to establish case specific responses that will ensure justifiable, cost-effective and defensible decisions about hazardous situations, The evolution or risk assessment is described in (Wharton, 2002). Risk assessment as a scientifically disciplined approach developed originally to analyse risk and safety problems for well-structured deterministic systems such as chemical or nuclear plants, aircraft and aerospace technologies but is now expected to deal with badly structured problems arising from for example, the creation of toxic wastes and the use of pesticides and their potentially extensive environmental effects. Key issues in risk assessment have been identified to include risk perception, estimation of perceived risk and the problem of defining what constitutes acceptable risk. Risk Assessment has been widely accepted as a fast evolving tool for environmental management technique, which is indispensable in the overall protection plan of human and ecological health. The application of risk assessment provides both a diagnostic and holistic tool for environmental management and the process can be expressed either by quantitative or qualitative terms (Asante-Duah, 2008). Risk assessment is gaining greater prominence as a structured approach to setting priorities. It can range from qualitative exercise where the risks are minor and database of knowledge fragile to quantified treatise where experience and the magnitude of possible events make it appropriate to apply sufficient resources to develop detailed approach to action.

\section{Risk Characterisation}

The final stage of risk assessment process brings together the results of the three stages enumerated earlier, hazard identification, doseresponse and human exposure, then determines the likelihood that people will experience any of the various forms of injury or disease associated with the contaminant or hazardous situation. The risk characterization stage summarizes and combines outputs of the exposure and toxicity assessments to characterize baseline risk, both in qualitative expressions and quantitative statements. The chemical-specific toxicity information is compared against both measured contaminant 
exposure levels and those levels predicted through fate and transport modeling to determine whether current or future levels at or near the site are of potential concern (Stigliani, 2015). Risks can be compared and ranked on a scale from small to large comparatively using specific comparison that involves side-by side evaluation of the risks associated with exposure to a few substances, products or activities and programmatic comparative risk assessment which refers to macro level comparison among many widely differing types of risks, usually to provide information for getting and budgetary priorities for hazard reduction.

\section{Risk Management}

Risk Management is the reduction of threats to life and property (and the environment) posed by known hazards whilst simultaneously accepting unmanageable risks and maximizing any associated benefits. According to (Smith,2010 and USEPA, 1991) stated the above definition. Risk a process whereby decisions are made to accept a known or assessed risk and/or the implementation of actions to reduce the consequences or probability of an occurrence. It implies that risk management process is set to accomplish the following

1. Determine which risks are unacceptable to society

2. Consider available control options and

3. Decide on appropriate ways to reduce or eliminate unacceptable risks.

Risk Management is an organized means of identifying and measuring risk and developing, selecting, and managing options for handling these risks. From the point of view of business consideration, risk management is defined by (Williams, 2005) as a general management function that seeks to identify, assess, and address the causes and effects of uncertainty and risk on an organization. The purpose of risk management is to enable an organization to progress towards its goals and objectives in the most direct, efficient and effective path. Risk cannot be avoided or eliminated entirely and it is suggested that in all forms of risk management, there are essentially three principles at play - the maximization of expected values, the avoidance of catastrophe and the discounting of remote possibilities. Risk management programs are typically directed at risk reduction (i.e. taking measures to protect human and environment against previously identified risk), risk mitigation (i.e. implementing measures to remove risk), and risk prevention (i.e. instituting measures to completely prevent the occurrence of risk). Risk reduction, mitigation and preventive programs generally help in the improvement of system efficiency and reliability; they can also facilitate an increase in the level of protection to public health and safety, as well as in the reduction of liability (Asante-Duah, 2008). Generally speaking, implementation of risk management aims at corrective (structured) type of measures and the preventive (non-structured) measures (Smith, 2010).

The key ingredients of an effective risk management include:
1. Pre-disaster planning
2. Preparedness/anticipation
3. Response
4. Recovery and reconstruction.

Formulation of risk management strategies should take into account basic considerations that both focus on human and technical varieties (USEPA, 1991; Asante-Duah, 2008). Items for such consideration include:

1. Technical and scientific viability

2. Societal concerns

3. Economic constraint

4. Political considerations

Government intervention in the management of risk through the application of regulatory control instruments provides a basis for controlling the extent to which people are allowed to put either themselves or others at risk (Wharton, 2002). The management of risk through laws and policy programmes by government forms the bedrock for enforcement and implementation. Risk management is taken to be the sum of actions taken to keep the risk associated with any activity at an acceptable level. Risk management adopts the following approaches to reduce hazards.

I. Command and control measures like regulations, and permits.

2. Enforcement actions.

3. Market-based economic incentives.

4. Promotion of pollution prevention.

The approaches to reduce hazards are achieved by means of regulatory and non-regulatory policy instruments or tools. Policy makers are given the responsibility of selecting the most effective policy tools to meet environmental goals.

\section{Communication of Risk}

Risk communication involves activities directed at increasing the public knowledge of risk issues and participation in risk management through dialogue with risk experts and policy makers (Heath, 2008). 
The main objective of any risk assessment is to protect public and ecological health. It is imperative therefore that the result of such assessment be passed on to all stakeholders, that people know about the identified hazards, their effects on human and ecological health and measures to control the impacts of such hazards. No approach to risk management is worth much unless the outcomes are effectively communicated to those who handle the risk inducing systems or processes and those put at risk (Heath, 2008). Effective risk communication is important for the implementation of comprehensive risk management programme (Asante-Duah, 2008). It is imperative that risk communication should consider and embrace several important elements in order to minimize or even prevent suspicion/outage from a usually cynical public, and serious consideration of the relevant elements should help move a potentially charged atmosphere to a responsible one, and one of co-operation and dialogue. Benefit of risk communication can therefore not be over emphasized. Risk communication is divided into two central treatments, the internal and external. To effectively communicate risk to those outside the organization requires that some steps be taken (Health, 2008).

The steps include:

1. Evaluation of risks to the public that may be caused by any process or systems.

2. Determination of who the stakeholders are and how they view the risks.

3. Open up communication, listening and addressing the emotions involved.

4. Making pertinent information available in an open and honest style.

5. Seeking support from other organizations and gaining independent evaluation.

6. Ensuring the needs of the media and addressing them.

7. Communicating clearly and in simple language.

8. Avoiding conflict and aggressive case presentation.

9. Involving the Public

10. Communicate a joint evaluation of the risk exposure faced by the community and get the joint evaluation team to publicly announce the findings.

11. Develop education and information strategies within the surrounding communication.

12. Getting feedback from the stakeholders.

Adoption of comparative technique in presenting risk information to the public is described more meaningful than are absolute numbers or probabilities especially for related risk issues (Slovic, 2014). Involvement of media in risk communication is also important. The benefits of such media coverage include quick dissemination of crucial information to the public that can allay unfounded fears and inspire confidence (USEPA ,1991).

\section{Application of Risk Assessment in Nigeria Oil and Gas Industry} Chevron Nig. Ltd has adopted facility risk assessment process as a Corporate Management tool to assess its pipeline systems (Udogwu, 2016). The steps/ approaches adopted included:

I. Prioritize and group pipelines to define the risk category

2. Gather background information on the pipeline to be able to make good decisions.

3. Estimate the likelihood and consequences of failure and risk rank to understand the problem.

4. Determine mitigation and monitoring plan, to solve the problem to ensure integrity of the pipeline system.

5. Review the system to manage change.

According to the Company the benefits of the risk control programme among others include:

1. Incident free operations

2. Good safety and environment performance

3. Sustainable reduction in capital and operation cost

4. Better legislative compliance

5. Good corporate image

6. Good community relations

7. Low liability and compensation claims

8. Higher productivity / increased revenue generation.

According to (Alcock and Mitchel,1998) in a pioneering work on the use of ASTM's (American Society for Testing \& Material) Risk-Based Corrective Action (RBCA) carried out a study at a historically contaminated site at Forcados Estuary, in Delta State, Nigeria adopting the principle that there must be a source, a target or receptor and a complete exposure pathway between the two for there to be a risk.

The steps adopted in RBCA method included:

1) Site Assessment and conceptual modeling development.

2) Site classification and Interim response 
3) Tier 1 evaluation - identification of chemicals and pathways of concern.

4) Tier 2 evaluation - a more detailed review of chemicals.

5) Tier 3 evaluation - more complex exposure modeling

6) Corrective action plan.

Furthermore, (Mac Neil, 2010) recommended a RiskBased approach in dealing with environmental issues of oil and gas exploration and production in Nigeria, suggesting the development of Tier 1 Risk Based Screening levels (RBSL). Risk assessment has been successfully used in the following situations and reviewed for purposes of this research.

1) Risk assessment, management and communication of drinking water contamination USEPA (1991).

2) Risk assessment of organic compounds in drinking water.

3) Explosion modeling and risk assessment.

4) Risk Assessment: Transport, storage and use of solvents and other flammable liquids (Mac Neil, 2010).

The research focused on soil considering that soil is the main repository all environmental pollution and poses great challenge in effort to restore them to fit for purpose status after contamination. Since some sites get contaminated to the extent that cleanup is required to avoid adverse effects on human and the environment risk assessment becomes a useful basis for soil quality criteria. This view has been expressed that soil cleanup criteria determines the feasibility of the technology required and the costs of remediation. To achieve optimal benefit from such exercise it is important that soil clean up criteria are based on sound scientific approach which helps the environmental quality standard (EQS) to developed through the application of risk assessment technique.

\section{Sampling Method}

The sample for this research was drawn by use of simple random sampling technique. At the first stage, a sampling frame was designed to depict the grid system across the West African gas pipeline community map see appendices.

The table 1 below was made by numbering the gridded community map of the study area $1-20$ cells. Also numbers 1-4 was assigned at the top of the map as well as code ABCDE at the right side of same map for easy identification of each settlements and cells. Settlements on each cell were identified and written on pieces of paper, folded and placed in a container, properly shaken together and then picked at random. The first numbers drawn from the container were 3 and recorded as code A3 Ewupe settlement; the second was number 11 recorded as code C3 Olorunda settlement. The exercise continued until twelve settlements were selected out of the 23 settlements that make up the communities in the study area from the twenty cells (20) in the grid. This is shown in table 2 .

Table: 1. Selection of settlements along pipeline right of way.

\begin{tabular}{llccc}
\hline & 1 & 2 & 3 & 4 \\
\hline $\mathrm{A}$ & 1 & 6 & 11 & 16 \\
$\mathrm{~B}$ & 2 & 7 & 12 & 17 \\
$\mathrm{C}$ & 3 & 8 & 13 & 18 \\
$\mathrm{D}$ & 4 & 9 & 14 & 19 \\
$\mathrm{E}$ & 5 & 10 & 15 & 20 \\
\hline
\end{tabular}

Table: 2 List of Settlements in each Cell.

\begin{tabular}{llll}
\hline S/N & Number Drawn & Code & Names of sampled Settlements \\
\hline 1 & 3 & A3 & Ewupe, Mosafejo, Etere, Isale. \\
2 & 11 & C3 & Olorunda, Owu, Toto-Owu, Itale. \\
3 & 10 & C2 & Igbesa, Ipatire, Okoomi, \\
4 & 19 & E3 & Badagry, Ajido, Igbade, Lemba, Mobame. \\
5 & 4 & A4 & Itoki, Ogbo, Otta, Ajibade. \\
6 & 14 & D2 & Araromi Ale, Gbanko, Agemowo, Iworo. \\
7 & 4 & A4 & Ijoko, Ajibade, Otta, Owode. \\
8 & 14 & D2 & Idigha Iyesi, Amunwo, Obale, Isako- Etedo. \\
9 & 10 & C2 & Ilogbo Eremi,Egundu, Bello, Oresa. \\
10 & 13 & D1 & Imeke, Araromi-Ale, Amunwo, Ikotun. \\
11 & 7 & B3 & Arobieye, Itori, Abiola, Oloya. \\
12 & 14 & D2 & Agbara, Ijanikin, Morogbo,Ojo. \\
\hline
\end{tabular}


A qualitative assessment of the hazards and risk due to the environmental incidents were assessed by use of the hazard and risk assessment Matrix (RAM). Factor analysis is a high powered multivariate statistical technique used in explaining observed relationships among numerous variables in terms of fewer and simpler mutually independent factors. This was achieved by collapsing a set of inter- correlated variables into smaller numbers of basic dimensions, which are capable of explaining a high percentage of the variance in the original data set. The basic dimension or the common factors are thus diagnostic of the underlying influence or structure,(Balogun, 2006).

Results:- Risk characterization using Risk Assessment Matrix

The research identified the various risks faced by the inhabitants of the settlements along the gas pipeline right of way, with a view to presenting an assessment of the risk to live, property and the environment. The following factors have been identified as potential hazards and risks posed to the settlers along the pipeline right of way: Risk is a function of probability and severity. Applying the risk assessment matrix in the characterization of risk, a scale of consequence rated $0-5$ was adopted to indicate the increasing severity of the identified hazards and risks to the pipeline settlers. The consequence was judged on the impact on human health, the environment and socio economic. Therefore the risk was classified using the matrix model to assess the effects on these variables:

1. The Probability of the fire incidence occurring along the pipeline right of way ranging from $\mathrm{A}$ to $\mathrm{E}$.

2. The severity of the incident on the People rated from 1 to 5 .

3. The effects on their socio economic lives such as loss of property and farmland etc rated from 1 to 5 .

Table .3: Risk Assessment Matrix Model

\begin{tabular}{|c|c|c|c|c|c|c|c|c|c|}
\hline \multicolumn{5}{|c|}{ Consequence } & \multicolumn{5}{|c|}{ Increasing Probability } \\
\hline$\frac{\mathscr{E}}{\frac{6}{2}}$ & 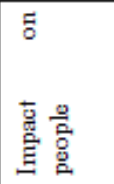 & 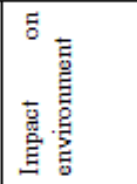 & 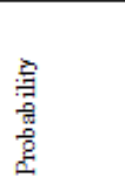 & 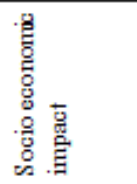 & 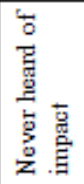 & 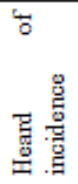 & 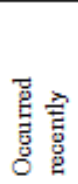 & 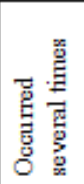 & 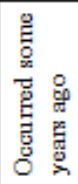 \\
\hline 0 & $\begin{array}{l}\text { No } \\
\text { injury }\end{array}$ & No impact & $\begin{array}{l}\text { No } \\
\text { damage }\end{array}$ & No impact & & & & & 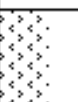 \\
\hline 1 & $\begin{array}{l}\text { Slight } \\
\text { injury }\end{array}$ & $\begin{array}{l}\text { Slight } \\
\text { impact }\end{array}$ & $\begin{array}{l}\text { Slight } \\
\text { damage }\end{array}$ & $\begin{array}{l}\text { Slight } \\
\text { impact }\end{array}$ & & & & & \\
\hline 2 & $\begin{array}{l}\text { Minor } \\
\text { injury }\end{array}$ & $\begin{array}{l}\text { Minor } \\
\text { impact }\end{array}$ & $\begin{array}{l}\text { Minor } \\
\text { damage }\end{array}$ & $\begin{array}{l}\text { Minor } \\
\text { impact }\end{array}$ & & & & & \\
\hline 3 & $\begin{array}{l}\text { Major } \\
\text { injury }\end{array}$ & $\begin{array}{l}\text { Confined } \\
\text { impact }\end{array}$ & $\begin{array}{l}\text { Localizad } \\
\text { damage }\end{array}$ & $\begin{array}{l}\text { Noticeable } \\
\text { impact }\end{array}$ & & & & & \\
\hline 4 & $\begin{array}{l}\text { Low } \\
\text { Fatality }\end{array}$ & $\begin{array}{l}\text { Confined } \\
\text { impact }\end{array}$ & $\begin{array}{l}\text { Localized } \\
\text { damage }\end{array}$ & $\begin{array}{l}\text { Noticeable } \\
\text { impact }\end{array}$ & & & & & \\
\hline 5 & $\begin{array}{l}\text { Multiple } \\
\text { Fatality }\end{array}$ & $\begin{array}{l}\text { Extensive } \\
\text { impact }\end{array}$ & $\begin{array}{l}\text { extensive } \\
\text { damage }\end{array}$ & $\begin{array}{l}\text { Colossal } \\
\text { impact }\end{array}$ & & & & & \\
\hline
\end{tabular}

Source; Model adapted from Shell Bulletin; 2002

\section{LEGEND}

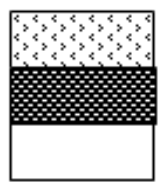

Low Risk

Medium Risk

High Risk

Source; Model adapted from Shell Bulletin; 2002 
Table 3 shows Risk Assessment Matrix Model. The risk assessment matrix is explained thus, using the three characters mentioned above; that is impact on people $(\mathrm{P})$, impact on environment $(\mathrm{E})$ and impact on socio-economic (S). The intersection of chosen column and a chosen row gave the risk classification. Risk is the unpleasant consequence of exposure to a hazard if no action situation is applied. Some of the people in the study area have lived there since their birth before the crossing of the pipeline. Some also claimed ignorant of threats such as fire outbreaks, explosion, vandalization etc. that could result from the facility until recently. Generally, petroleum products especially petrol has never been in short supply from the refineries or affected by economic scarcity. But with increase in technological and industrial development and with increased number of auto machines, the demand for petrol, diesel, gas and even kerosene increased. Research has shown that oil and gas pipeline incidence has increased recently in Nigeria, because of the level of unemployment, economic downturn and agitation against alleged marginalization of oil producing and host communities in the Niger Delta. Pipeline vandalization which is one major hazard to the pipeline dwellers had remained a major concern to government and oil and gas operators in Nigeria. The magnitude of the risk to human and ecological environment was a function of exposure to the hazard.

Table 4: Risk Characterization on People (e.g. fire outbreak on Pipeline ROW)

\begin{tabular}{|c|c|c|c|c|c|c|c|c|}
\hline & & & & & $\begin{array}{l}\text { rea } \\
\text { bal }\end{array}$ & $\begin{array}{l}\text { ng } \\
\text { lity }\end{array}$ & & \\
\hline $\begin{array}{l}\text { Sevent } \\
\mathrm{y}\end{array}$ & People & $\begin{array}{l}\text { Environme } \\
\text { nt }\end{array}$ & $\begin{array}{l}\text { Socio- } \\
\text { economi } \\
\text { c }\end{array}$ & A & B & $\mathrm{C}$ & D & $\mathrm{E}$ \\
\hline 0 & No injury & & & & & & & \\
\hline 1 & Slight injury & & & & & & & \\
\hline 2 & Minor injury & & & & & & & \\
\hline 3 & Major injury & & & & & & & \\
\hline 4 & Low fatality & & & & & & & \\
\hline 5 & $\begin{array}{l}\text { Multiple } \\
\text { fatality }\end{array}$ & & & & & & & \\
\hline
\end{tabular}

D5P

\section{Legend}

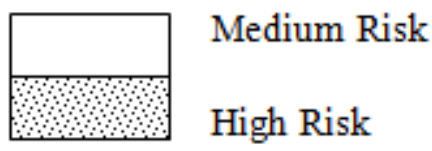

Table 4 above shows the risk characterization on people (e.g. fire outbreak on pipeline right of way). The human health risk associated with the different oil/gas fire outbreaks in the country and the world at large has shown that the disaster was enormous and when expressed either in monetary terms or through property damage was extremely high (Cutter , 2003).

A review of literature on incidents of fire outbreaks along oil and gas pipeline has established that the immediate health risk was severe burns and death. All the deaths recorded in the incidents were attributed to this factor as most victims had second and third degree burns. The fatalities resulting from oil and gas pipeline fire incidents have become the single most widely published aspects of fire disasters as fatality carries unacceptable risk rating. Fatality 
rates were usually high due mainly to the saturation of vapour pressure in the atmosphere prior to explosion and ignition of fire. The deafening noise preceding the explosion and the inhalation of the released gas were all identified health risk (Esinaulo, 2004). Therefore it is important to establish that settlement within and around oil/gas right of way are the most vulnerable to these health risks. The risk characterization on the people in table 4 showed severity rating of " 5 " under multiple fatality columns. The risk characterization was the intersection of the row and column was therefore "D5" (P) which was in the high risk zone. The incident occurred several times in the country and other parts of the world with recorded fatalities and health impacts.

\section{Risk characterization of an impacted soil medium by pipeline fire outbreak}

The physical environment along the pipeline right of way where fire outbreak has occurred resulting from oil/gas explosion showed degraded, bare, charred soil, resulting in the depopulation of organism and caused ecological imbalance, (Esinaulo,2004). The immediate effect of oil fire on the environment was soil heating which had potential to cause environmental dislocation. According to (Clark,2015) the loss of protective plant and litter cover increases the hydrophobility and erosion. The populations at risk at such incidents are those along the pipeline right of way, who farms and dwell around the pipelines. The nauseating odour from the impacted soil is a health risk and sometimes when these sites are left uncleaned for some years could be a potential hazard for an imminent fire outbreak in the future. The odour situation affects the inhabitants' recreational functions along the right of way. The damaged soil will lead to poor crop yield which could lead to malnutrition and diseases epidemic. The risk characterization was the intersection of the row and column, was therefore 'e' $5(\mathrm{E})$ which showed in the overall risk assessment model that the incident had occurred recently and several times and is rated very high.

Table 5. Risk Characterization on the Environmental Media

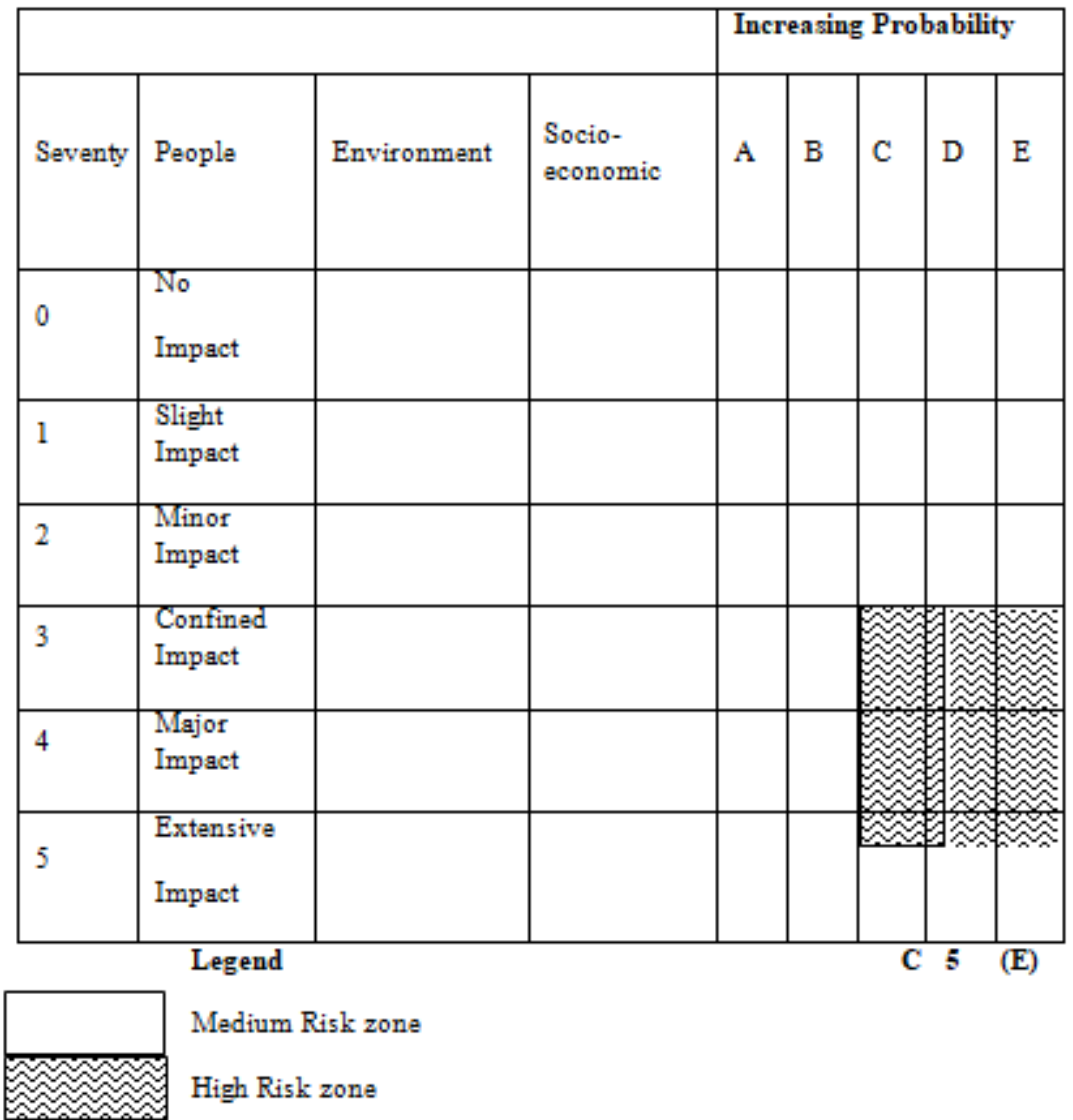


Table 6. Risk Characterization on Socio-economic

\begin{tabular}{|c|c|c|c|c|c|c|c|c|}
\hline \multicolumn{4}{|c|}{ Consequence } & \multicolumn{5}{|c|}{$\begin{array}{l}\text { Increasing } \\
\text { Probability }\end{array}$} \\
\hline Seventy & People & Environment & $\begin{array}{l}\text { Socio- } \\
\text { economic }\end{array}$ & A & B & $\mathrm{C}$ & D & E \\
\hline 0 & $\begin{array}{l}\text { No } \\
\text { Impact }\end{array}$ & & & & & & & \\
\hline 1 & $\begin{array}{l}\text { Slight } \\
\text { Impact }\end{array}$ & & & & & & & \\
\hline 2 & $\begin{array}{l}\text { Minor } \\
\text { Impact }\end{array}$ & & & & & & & 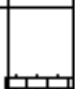 \\
\hline 3 & $\begin{array}{l}\text { Localized } \\
\text { Impact }\end{array}$ & & & & & & & 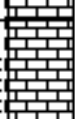 \\
\hline 4 & $\begin{array}{l}\text { Major } \\
\text { Impact }\end{array}$ & & & & & 藍 & 产 & 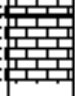 \\
\hline 5 & $\begin{array}{l}\text { Extensive } \\
\text { Impact }\end{array}$ & & & & & & & \\
\hline
\end{tabular}

Legend

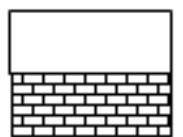

Socio-economic risk of settlements along transmission pipelines

The socio-economic impact in this study considered the risk of loss of farm lands, buildings, fishing/livestock farms etc. the study found out that there are direct and indirect impacts on settlements as a result of the project:

\section{a. Direct Cost}

- $\quad$ Loss of farmland

- $\quad$ Loss of buildings

- Loss of sacred Areas (shrine, cemeteries)

- $\quad$ Disruption of ecosystem

- $\quad$ Environmental degradation

- Displacement of people from their homes

b. Indirect Cost

Cost of liability and compensation

Resettlement of displaced people
Medium Risk zone

High Risk zone 
vulnerability assessment is properly defining the ratings for impact of loss and vulnerability (Slovic, 2014). These definitions may vary greatly from facility to facility. For example, the amount of time the settlements is cut off from use of such amenities is an important part of impact of loss. If the facility being assessed is a transmission pipeline, a shut down downtime of a few minutes of fuel supply resulting from the incident may be a serious impact of loss, while for a Social Security office a downtime of a few minutes would be minor. A sample set of definitions for impact of loss is provided below. These definitions are for an organization that generates revenue by serving the public, e.g. a Petrol Station

- Devastating: The facility is damaged/contaminated beyond use. Most items/assets are lost, destroyed, or damaged beyond repair/restoration. The number of visitors the facility may be reduced by up to $75 \%$ for a reasonable period of time.

- Severe: The facility is partially damaged/contaminated. Examples include partial structure burning resulting in careless fuel handling, smoke, impact, or fire damage to some areas. Some items/assets in the facility are damaged beyond repair, but the facility remains mostly intact. The entire facility may be closed for a period of up to four weeks and a portion of the facility may be closed for an extended period of time (more than one month). Some assets may need to be moved to remote locations to protect them from environmental damage. The number of visitors to the facility and others in the organization may be reduced by up to $80 \%$ for a long period of time.

- Noticeable: The facility is temporarily closed or unable to operate, but can continue without an interruption of more than one day. A limited number of assets may be damaged, but the majority of the facility is not affected. The number of visitors to the facility and others in the organization may be reduced by up to $25 \%$ for a limited period of time.

- Minor: The facility experiences no significant impact on operations (downtime is less than four hours) and there is no loss of major assets (PPMC, 2005).

Vulnerability assessment could also be a combination of the attractiveness of a facility as a target and the level of deterrence and/or defense provided by the existing countermeasures. Target attractiveness is a measure of the asset or facility in the eyes of an aggressor and is influenced by the function and/or symbolic importance of the facility (Williams, 2005). Sample definitions for vulnerability ratings are as follows:

- Very High: This is a high profile facility that provides a very attractive target for potential adversaries, and the level of deterrence and/or defense provided by the existing countermeasures is inadequate.

- High: This is a high profile regional facility or a moderate profile national facility that provides an attractive target and/or the level of deterrence and/or defense provided by the existing countermeasures is inadequate.

- Moderate: This is a moderate profile facility (not well known outside the local area or region) that provides a potential target and/or the level of deterrence and/or defense provided by the existing countermeasures is marginally adequate.

- Low: This is not a high profile facility and provides a possible target and/or the level of deterrence and/or defense provided by the existing countermeasures is adequate. 


\section{Factor Analysis}

Table 7: Relationship of factors in Rotated Space

Component Transformation Matrix

\begin{tabular}{|l|r|r|r|r|r|r|r|}
\hline Component & \multicolumn{1}{|l|}{1} & \multicolumn{1}{l|}{2} & \multicolumn{1}{l|}{3} & \multicolumn{1}{l|}{4} & 5 & \multicolumn{1}{l|}{6} & 7 \\
\hline 1 & -.664 & .525 & .451 & .129 & .236 & -.083 & -.045 \\
2 & .678 & .327 & .495 & .371 & .110 & .190 & .053 \\
3 & .192 & .049 & .134 & -.757 & .582 & .069 & -.163 \\
4 & -.105 & -.507 & -.054 & .491 & .669 & .094 & -.177 \\
5 & -.088 & .265 & -.399 & .016 & .232 & .556 & .632 \\
6 & .176 & .533 & -.609 & .176 & .194 & -.307 & -.389 \\
7 & .114 & -.057 & .035 & .012 & .236 & -.735 & .621 \\
\hline
\end{tabular}

Extraction Method: Principal Component Analysis.

Rotation Method: Varimax with Kaiser Normalization.

Table 8. Unrotated factor Loading

Component Matrix

\begin{tabular}{|c|c|c|c|c|c|c|c|}
\hline & \multicolumn{7}{|c|}{ Component } \\
\hline & 1 & 2 & 3 & 4 & 5 & 6 & 7 \\
\hline Sex & .389 & .128 & .548 & .650 & .208 & .143 & .147 \\
\hline Age & .468 & .423 & .388 & 1.978E-02 & -.319 & -.275 & .225 \\
\hline Edu level & .417 & .358 & $-9.83 E-02$ & .114 & -.578 & -.131 & $-8.54 \mathrm{E}-02$ \\
\hline Occupational status & .472 & .517 & $-9.04 \mathrm{E}-02$ & $-8.33 E-02$ & -.142 & -.457 & $-7.15 E-02$ \\
\hline Income status & -.444 & .616 & $-4.65 E-02$ & 5.263E-02 & -.228 & .214 & -.131 \\
\hline Secondary activities & .507 & .421 & $-8.63 E-03$ & -.161 & .104 & -.390 & $-4.69 \mathrm{E}-02$ \\
\hline Length of stay & .630 & .263 & .348 & $-9.88 E-02$ & -.217 & $-6.14 \mathrm{E}-02$ & .180 \\
\hline Land tenure system & -.220 & 9.657E-02 & .443 & $-1.00 \mathrm{E}-01$ & .236 & $-9.53 E-02$ & -.598 \\
\hline Age of dwelling unit & .712 & .313 & -.100 & -.315 & .175 & .312 & $5.998 E-02$ \\
\hline Type of stay & .355 & .216 & .352 & -.303 & -.104 & .391 & -.117 \\
\hline Knowledge of operation & .389 & .128 & .548 & .650 & .208 & .143 & .147 \\
\hline Presence of oil company & .188 & .482 & -.665 & .420 & 3.708E-02 & .141 & $1.879 \mathrm{E}-02$ \\
\hline $\begin{array}{l}\text { Perception of } \\
\text { environmental problems }\end{array}$ & .689 & .330 & $-9.04 \mathrm{E}-02$ & -.413 & 8.725E-02 & .293 & $-1.39 E-02$ \\
\hline Indication of benefits & -.749 & .529 & .172 & -.114 & 7.733E-02 & 6.927E-03 & .163 \\
\hline $\begin{array}{l}\text { Awareness of } \\
\text { hazards/risk }\end{array}$ & -.188 & .359 & $-9.41 E-02$ & .238 & .438 & -.272 & -.394 \\
\hline Perception of hazards/risk & -.759 & .525 & .175 & -.116 & $8.286 \mathrm{E}-02$ & 2.223E-03 & .139 \\
\hline $\begin{array}{l}\text { Approx. distance of } \\
\text { dwelling }\end{array}$ & .440 & .530 & $9.504 \mathrm{E}-02$ & 5.993E-02 & .133 & -.157 & -.190 \\
\hline Dwelling along pipeline & .188 & .482 & -.665 & .420 & 3.708E-02 & .141 & $1.879 \mathrm{E}-02$ \\
\hline Opinion on right or wrong & $-1.00 \mathrm{E}-01$ & .200 & -.202 & -.200 & .465 & -.273 & .509 \\
\hline $\begin{array}{l}\text { Awareness of existence of } \\
\text { laws }\end{array}$ & -.479 & .636 & 1.257E-02 & $9.036 \mathrm{E}-02$ & -.222 & .217 & -.154 \\
\hline $\begin{array}{l}\text { Identification of potential } \\
\text { hazards }\end{array}$ & -.681 & .555 & .160 & -.158 & $8.678 \mathrm{E}-02$ & $8.812 \mathrm{E}-03$ & .138 \\
\hline Number of fire incident & -.764 & .467 & .117 & $-7.60 \mathrm{E}-02$ & $-6.76 \mathrm{E}-02$ & $6.744 \mathrm{E}-02$ & .118 \\
\hline $\begin{array}{l}\text { Knowledge of } \\
\text { enlightenment }\end{array}$ & .681 & .301 & $-2.68 \mathrm{E}-02$ & -.318 & .382 & .208 & $-4.55 \mathrm{E}-02$ \\
\hline
\end{tabular}

Extraction Method: Principal Component Analysis.

a. 7 components extracted.

Table 7, above showed factor loading of each variable on seven (7) unrotated common factors. Table 8 showed that unrotated factors are not completely diagnostic of the pattern of the real influences behind the data sets, in other words they are not stable and do not make meaningful pattern in factor loading. 


\section{Testing of Hypotheses Hypothesis 1}

$\mathrm{H}_{\mathrm{o}}$ : $\quad$ There is no significant hazard and risk that have effects on the lives of settlers along the West African gas pipeline right of way.

$\mathrm{H}_{\mathrm{i}}$ : There is hazard and risk that have significant effects on the lives of settlers along the West African gas pipeline right of way.

The T- test used for these hypotheses is a two tailed test. Two independent variables each were used in pair for the comparison; awareness of the hazards and risk along the pipeline right of way and the identification of these hazards and risks by settlers for the first hypothesis. The pair for the second hypothesis is; awareness of the hazards and risks along the pipeline right of way and the knowledge of the safety measure to create awareness along the pipeline right. The pair for the third hypothesis is; awareness of hazards and risks along the pipeline right of way and tenure system of household members. In application of $\mathrm{T}$ - test, it is generally known that the normal curve is distributed about a mean of zero, with a standard deviation of one (1). A t-score can fall along the normal curve either above or below the mean; either plus or minus some standard deviation unit from the mean. The result of the two tailed test for the first hypothesis is shown in the table below;

Table 9. T-test Showing Paired Sample Statistics

Paired Samples Statistics

\begin{tabular}{|c|c|c|c|c|c|}
\hline & & Mean & $\mathrm{N}$ & Std. Deviation & $\begin{array}{c}\text { Std. Error } \\
\text { Mean }\end{array}$ \\
\hline \multirow[t]{2}{*}{$\begin{array}{l}\text { Pair } \\
1\end{array}$} & $\begin{array}{l}\text { Awareness of } \\
\text { hazards/risk }\end{array}$ & 1.25 & 545 & .434 & .019 \\
\hline & $\begin{array}{l}\text { Identification of } \\
\text { potential hazards }\end{array}$ & 2.26 & 545 & 1.274 & .055 \\
\hline \multirow[t]{2}{*}{$\begin{array}{l}\text { Pair } \\
2\end{array}$} & $\begin{array}{l}\text { Awareness of } \\
\text { hazards/risk }\end{array}$ & 1.25 & 545 & .434 & .019 \\
\hline & safey precautions & 3.1719 & 545 & .87938 & .03767 \\
\hline \multirow[t]{2}{*}{$\begin{array}{l}\text { Pair } \\
3\end{array}$} & $\begin{array}{l}\text { Awareness of } \\
\text { hazards/risk }\end{array}$ & 1.24 & 540 & .430 & .019 \\
\hline & Measure to disuse & 3.0370 & 540 & .97456 & .04194 \\
\hline
\end{tabular}

Table 10. T-test showing all samples Test.

Paired Samples Test

\begin{tabular}{|c|c|c|c|c|c|c|c|c|c|}
\hline & & \multicolumn{5}{|c|}{ Paired Differences } & \multirow[b]{3}{*}{$t$} & \multirow[b]{3}{*}{$d f$} & \multirow[b]{3}{*}{ Sig. (2-tailed) } \\
\hline & & \multirow[b]{2}{*}{ Mean } & \multirow[b]{2}{*}{ Std. Deviation } & \multirow{2}{*}{$\begin{array}{l}\text { Std. Error } \\
\text { Mean }\end{array}$} & \multicolumn{2}{|c|}{$\begin{array}{l}95 \% \text { Confidence } \\
\text { Interval of the } \\
\text { Difference }\end{array}$} & & & \\
\hline & & & & & Lower & Upper & & & \\
\hline $\begin{array}{l}\text { Pair } \\
1\end{array}$ & $\begin{array}{l}\text { Awareness of } \\
\text { hazards/risk - } \\
\text { Identification of } \\
\text { potential hazards }\end{array}$ & -1.01 & 1.220 & .052 & -1.11 & -.90 & -19.273 & 544 & .000 \\
\hline $\begin{array}{l}\text { Pair } \\
2\end{array}$ & $\begin{array}{l}\text { Awareness of } \\
\text { hazards/risk - safey } \\
\text { precautions }\end{array}$ & -1.9205 & .85999 & .03684 & -1.9929 & -1.8481 & -52.134 & 544 & .000 \\
\hline $\begin{array}{l}\text { Pair } \\
3\end{array}$ & $\begin{array}{l}\text { Awareness of } \\
\text { hazards/risk - } \\
\text { Measure to disuse }\end{array}$ & -1.7926 & 1.00226 & .04313 & -1.8773 & -1.7079 & -41.562 & 539 & .000 \\
\hline
\end{tabular}

Decision Rule: From the above table1.10, it is observed that the computed t-scores $(-19.273)$ for pair one, $(-52.134)$ for pair two and $(-41.562)$ for pair three exceeds the value of $t$, indicated in the table. Also, from the T- Test, there is significant difference $(p<0.05)$ between the comparisons done for the three pairs, so we reject the null hypothesis and accept the three research hypotheses stated in chapter three (3.9).

\section{Conclusion}

From the analysis by factor loading in chapter four 
using the factor analysis for the seven (7) factors, the first common factor had high positive scores on perception of hazards by settlers along the pipeline right of way. This suggests that there are hazards inherent along the pipeline right of way. Furthermore, a test of significant effect of the perceived hazards by settlers along the pipeline right of way on their lives, property and the environment was highly significant as proved in this research. Available statistics from Nigeria National Petroleum Corporation (NNPC) on fire incident alone since 2000 to date in Nigeria is put at about eight hundred (2000) cases of pipeline incidents involving fire outbreaks. Oil spillage cases are estimated at seven hundred (1500) cases. Furthermore, considering that there are settlements along these pipeline routes, this means that lives, properties and agricultural lands have been lost. This does not portray the country in good light as a Nation in support of the global initiative of the United Nations Campaign for sustainable environment development. Therefore, the research concludes with the following assertions;

1. That pipeline right of ways has the potential of causing hazards to lives, property and the environment.

2. As pipelines poses risks and hazards to their environment, so doe's human activity in the vicinity, this is increased with the growth in population along pipeline right of ways accelerated by urbanization in urban areas and cities.

3. The research revealed that the Federal, States and the local governments have not systematically considered risks and hazards to the public from transmission pipelines; hence the laws are not explicit on how to the regulate land use along pipeline right of way in the country.

Therefore this research urges the government and oil and gas company operators to arise and save the country of the huge loss in human and natural resources occasioned by the disaster that occurs along pipeline right of ways.

Vulnerability assessment also shows that the attractiveness of a facility as a target by pipeline vandals makes the settlements very vulnerable and the level of deterrence and/or defense provided by government or pipeline owners are not adequate to countermeasures adopted by the vandals (Onwurah,2009). Target attractiveness is a measure of the asset or facility in the eyes of an aggressor and is influenced by the function and/or symbolic importance of the facility. Sample definitions for vulnerability ratings for the transmission pipelines in Nigeria are Very High: This is because pipelines are high profile facility that provides a very attractive target for potential adversaries, and the level of deterrence and/or defense provided by the existing countermeasures is inadequate.

\section{References}

1. Alcock and Mitchel (1998) Use of RBCA for Historically Contaminated site in the

2. Niger Delta. Workshop paper delivered in Rivers State sponsored by SPDC.

3. Asante- Duah, K. (2008) Assessment in Environmental Management. J Wiley and sons. U.S.A 205pp.

4. Balogun, O. (2006): Dissertation Submitted to the Department of Urban and Regional Planning of the University of Ibadan, Nigeria.

5. Clark , B ( 2015) Fire Effects Guide: National wild life coordinating Group.USA -EMS Group.

6. Cohrssen , J. J and Covello, V.T. (2009) Risk Analysis: A guide to principles and

7. methods for analyzing health and environmental risks. National Technical

8. Information Services US department of Commerce. Springfield Press.

9. Cutter, S.L. ( 2003) Living with Risk: The geography of Technological Hazards. Cambridge University Press. U.K. 455pp.

10. Esinaulo. M, L, (2004) Selected case studies on risk assessment and management of oil and gas pipeline outbreaks in the Niger delta region of Nigeria. Dissertation Submitted for the award of $\mathrm{PhD}$ to the Institute of Geosciences and Space Technology (RSUST) Port Harcourt, Rivers State, Nigeria.

11. Heath, R (2008) Crisis Management for Managers and Executives. Financial Times and Pitman Publication. London.

12. Lawrence W.W.(1996) Acceptable Risk. Science and the Determination of Safety William Kaufman Press.

13. Mac Neil (2010) Risk Assessment . Transport, Storage and use of solvents and other Flammables liquids.

14. Nigeria National Petroleum Corporation; Pipeline and Products Marketing Company Bulletin, (2005); Nigeria National Petroleum Corporation; Department of Petroleum Resource Bulletin, PPMC (2013).

15. Onwurah, I. N. (2009) A Perspective of Industrial and Environmental Biotechnology. Snaap Press Ltd.

16. Schneider, S.(2001) Renewable Energy Prosoects, Comparative Risk Assessment of Energy Systems.

17. Stigliani W.M. (2015) Risk Assessment and Decision support Tools.

18. Workshop paper delivered on Environmental Pollution and Applicability of Remediation Tecnologies in Africa organized by SPDC.

19. Slovic, P (2014) Beyond Numbers: A Broader Perspective on Risk .

20. Edited by Mayor and Hollander. Stannic Press, Germany.

21. Smith, J.W.(2010) Environmental Hazards: Assessing Risk and Reducing Disaster. $2^{\text {nd }}$ Edition Routledge.233pp.

22. Udogwu C.A. (2016) The Benefits of a Good Risk Control Programmes in the Petroleum industry and the Nigerian Environment. A workshop at PTI Efurrum Warri, Nigeria.

23. USEPA(1991) Environmental Risk . Guide to Analysising and Reducing Risk.

24. Rusheel No. 905/9-91-017.

25. Wharton, F (2002) Risk Management: Basic Concepts and General Principles John Wiley Press, USA, 255pp.

26. Williams, C. A. (2005) Risk Management and Insurance.

27. $7^{\text {th }}$ Edition McGraw Hill, Cambridge England.303pp. 